\title{
ANALISIS PERBANDINGAN HARGA MOBIL BEKAS MENGGUNAKAN METODE FUZZY INFERENCE SYSTEM (FIS) MAMDANI DAN TSUKAMOTO
}

\author{
S. YURIDA ${ }^{1}$, K. OKTAFiAnTO ${ }^{2}$, R. YULiastuti ${ }^{3}$ \\ ${ }^{1}$ Program Studi Matematika FMIPA Universitas PGRI Ronggolawe, sienyyurida@gmail.com \\ ${ }^{1}$ Program Studi Matematika FMIPA Universitas PGRI Ronggolawe, kresnaoktafianto@unirow.ac.id \\ ${ }^{1}$ Program Studi Matematika FMIPA Universitas PGRI Ronggolawe, riitahabibi@gmail.com
}

\begin{abstract}
Abstrak
Pada dasarnya dalam memperkirakan harga mobil bekas belum digunakan suatu metode tertentu, khususnya metode logika fuzzy. Logika fuzzy memiliki lebih dari satu metode dalam perhitungan perkiraan hasil suatu kasus tertentu. Penelitian ini bertujuan untuk memberikan solusi dengan cara membandingkan metode fuzzy Tsukamoto dengan metode fuzzy Mamdani dalam kasus memperkirakan harga mobil bekas dan menentukan metode manakah yang lebih baik. Metode penelitian menggunakan metode komparasi atau perbandingan, dalam membandingkan perhitungannya menggunakan nilai rata-rata dari hasil yang diperoleh pada kedua metode fuzzy tersebut. Hasil dari penelitian ini dapat diambil kesimpulan bahwa perkiraan Mobil bekas menggunakan metode fuzzy Tsukamoto lebih mahal dibandingkan dengan hasil perkiraan harga mobil bekas menggunakan metode fuzzy Mamdani dengan selisih rata-rata Rp.21.800.000,00 atau sekitar $\pm 22 \%$.
\end{abstract}

Kata kunci: Fuzzy Tsukamoto, Fuzzy Mamdani, Harga Mobil, Penelitian Komparasi

\section{Pendahuluan}

Jual beli mobil merupaka kegiatan transaksi yang sering kita jumpai, bahkan kegiatan transaksi tersebut bisa ditemukan di surat kabar, dan melihat iklan di internetdengan harga yang sangat bervariasi baik dalam kondisi baru maupun kondisi bekas. Untuk menentukkan harga beli mobil bekas setidaknya ada beberapa hal yang perlu diperhatikan. Beberapa diantaranya adalah merk mobil, warna, tahun pembuatan, jarak tempuh,dan kondisi mobil bekas tersebut [1]. Salah satu cara yang bisa digunakan dalam memperkirakan harga mobil bekas adalah menggunakan logika fuzzy, karena terdapat beberapa data yang dapat digunakan dalam melakukan penghitungan guna mendapatkan perkiraan harga mobil bekas. Di dalam logika fuzzy terdapat beberapa metode dan stiap metode memiliki cara penghitungan yang berbeda. Metode fuzzy Mamdani dan metode 
fuzzy Tsukamoto dalam penghitungannya memiliki cara yang berbeda pada mesin inferensi dan deffuzyfikasi [2] [3].

Masalah yang timbul adalah bagaimana menentukan metode yang lebih efektif antara metode fuzzy Mamdani dan metode fuzzy Tsukamoto dalam memperkirakan harga mobil bekas yang sesuai berdasarkan merk, warna,tahun pembuatan, kisaran jarak dan kondisi mobil bekas tersebut. Untuk menerapkan dan membandingakan kedua metode tersebut, penyusunan output sebagai bahan perbandingan antara kedua metode tersebut dalam kasus perkiraan harga mobil bekas.

\section{Landasan Teori}

\subsection{Logika Fuzzy}

Logika fuzzy adalah suatu cara yang tepat untuk memetakan suatu ruang input ke dalam ruang output [4][5].

Penelitian Komparasi "Kata "Komparasi” dalam bahasa inggris comparation, yaitu perbandingan. Maka dari kata tersebut menunjukan bahwa penelitian ini, peneliti bermaksud mengadakan perbandingan kondisi yang ada dan apakah kedua kondisi tersebut sama atau ada perbedaan".

\subsection{Cara kerja Logika Fuzzy}

Metode Tsukamoto dan metode Mamdani memiliki algoritma yang hampir sama dalam melakukan fuzzyfikasi dan aturan yang digunakan dalam bentuk $I F \ldots T H E N$. Berikut penjelasannya.

1. Fuzzyfikasi

"Proses untuk mengubah input sistem yang mempunyai nilai tegas menjadi variabel linguistik menggunakan fungsi keanggotaan yang disimpan dalam basis pengetahuan fuzzy" [6]

2. Pembentukan basis pengetahuan Fuzzy (Rule dalam bentuk $I F \ldots T H E N)$.

$$
\text { IF }(X I S A) \text { and }(Y \text { IS B) THEN (Z IS C) }
$$

Dimana $A, B$, dan $C$ adalah himpunan fuzzy. Walaupun terdapat langkah penyelesaian yang hampir sama, terdapat perbedaan dalam proses mesin inferensi dalam evaluasi aturan dan proses defuzzyfikasi pada kedua metode tersebut. Perbedaan antara metode fuzzy Tsukamoto dan metode fuzzy Mamdani antara lain [7]:

a. Metode Fuzzy Tsukamoto

(a) Saat proses evaluasi aturan dalam mesin inferensi, metode fuzzy Tsukamoto menggunakan fungsi implikasi $M I N$ untuk mendapatkan nilai $\alpha$-predikat tiap-tiap rule $\left(a_{1}, a_{2}, a_{3} \ldots a_{n}\right)$. Masing-masing nilai $\alpha$-predikat digunakan untuk menghitung hasil inferensi secara tegas (crisp) masing-masing rule $\left(z_{1}, z_{2}, z_{3} \ldots z_{n}\right)$.

(b) Proses defuzzyfikasi pada metode Tsukamoto menggunakan metode rata-rata (Average) dengan rumus berikut:

$$
z=\frac{\sum a_{1} z_{1}}{\sum a_{1}}
$$

b. Metode Fuzzy Mamdani

(a) Saat melakukan evaluasi aturan dalam mesin inferensi, metode Mamdani menggunakan fungsi $M I N$ dan komposisi antar-rule menggunakan fungsi $M A X$ untuk menghasilkan himpunan fuzzy baru. 
(b) Proses defuzzyfikasi pada metode Mamdani menggunakan metode Centroid dengan rumus berikut:

$$
z=\frac{\int \mu(z) \dot{z} d z}{\int \mu(z) d z}
$$

\section{Metode Penelitian}

\subsection{Gambaran Umum}

Penyusunan perhitungan sistematis menggunakan metode fuzzy Tsukamoto dan metode fuzzy Mamdani dalam kasus perkiraan harga mobil bekas dilakukan melalui beberapa tahap yaitu sebagai berikut:

\subsection{Studi Literatur}

Pada tahap ini, dikumpulkan bahan, informasi, keterangan dan teori dalam buku, dan konsultasi dengan para ahli atau narasumber serta rujukan dari artikel yang berhubungan dengan metode fuzzy Tsukamoto dan metode fuzzy Mamdani serta referensi lain.

\subsection{Analisis Kebutuhan}

Pada tahap ini, ditentukan kebutuhan apa saja yang diperlukan dalam menyusun perhitungan sistematis pada metode fuzzy Tsukamoto dan metode fuzzy Mamdani, terutama menyusun himpunan fuzzy dan fungsi keanggotaan dalam fuzzyfikasi, mengetahui atribut linguistik dan numeris yang digunakan dalam fungsi keanggotaan fuzzy, serta aturan-aturan yang digunakan untuk mesin inferensi. Himpunan fuzzy dan fungsi keanggotaan untuk fuzzyfikasi dalam kasus perkiraan harga mobil bekas dibuat dengan menggabungkan antara representasilinear naik dan representasi linear turun sehingga menjadi himpunan fuzzy sebagai berikut: Himpunan fuzzy tersebut dapat digu-

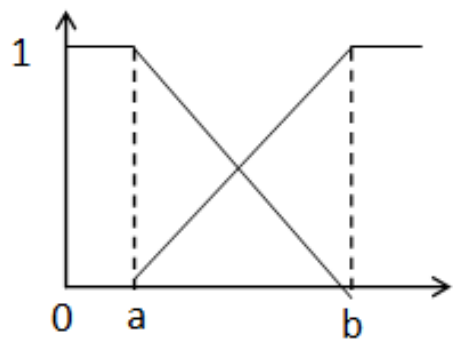

Gambar 1: Gambar Himpunan Fuzzy yang Digunakan Dalam Fuzzyfikasi untuk Kasus Perkiraan Harga Mobil bekas

nakan untuk atribut linguistik yang digunakan dalam fuzzyfikasi. Sebelum mendapatkan atribut tersebut, dicari suatu permasalahan seputar perkiraan harga mobil bekas.

\subsection{Menentukan Variabel}

Atribut linguistik logika fuzzy untuk perkiraan harga mobil bekas adalah kisaran kondisi, kisaran jarak yang telah ditempuh dan kisaran harga mobil bekas. Maka yang menjadi objek penelitian adalah kisaran kondisi, warna, merk, kisaran jarak yang telah ditempuh dan kisaran harga mobil bekas. 


\subsection{Menentukan Sampel}

Wawancara dilakukan terhadap narasumber yang berprofesi dibidang jual-beli mobil bekas di Tuban, mobil bekas yang akan diambil sampelnya merupakan, mobil bekas yang dimiliki setiap narasumber dibatasi dari mobil keluaran tahun 2000 hingga tahun 2015. Mobil yang akan dijadikan sampel dibatasi dari merk Toyota, Honda, Suzuki, Nissan, Daihatsu.

\subsection{Mengumpulkan Data}

Pada tahap ini, dikumpulkan data dan informasi yang dibutuhkan yang berkaitan dengan variabel, pengumpulan data dilakukandengan menggunakan metode wawancara dan observasi. Wawancara dilakukan untuk dimintai data mengenai kisaran kondisi, kisaran jarak tempuh serta kisaran harga mobil bekas. Dalam penyusunan lembar wawancara, ditentukan pedoman wawancara yang digunakan. Untuk menentukan nilai dari variabel numeris untuk kondisi mobil bekas dan kisarannya, pedoman wawancara disusun terstruktur, yaitu pedoman wawancara yang dibuat terperinci dan membentuk pilihan ganda sehingga cukup ditandai pilihan jawaban yang sesuai dengan jawaban narasumber, sedangkan untuk menentukan nilai dari variable numeris untuk kisaran jarak tempuh untuk kategori jarang pakai dan rutin pakai, serta untuk kisaran harga mobil bekas untuk kategori murah dan mahal, disiapkan pertanyaan essai yang akan dijawab oleh narasumber sesuai dengan isi pertanyaan dan berdasarkan pengalaman dari narasumber.

\section{Hasil dan Pembahasan}

\subsection{Data Uji Coba}

Pada tahap ini, didapatkan hasil wawancara dari beberapa tempat di Tuban. Wawancara meliputi pertanyaan untuk mendapatkan variabel numeris dimana dalam kasus perkiraan mobil bekas, atribut linguistiknya terdiri dari kondisi, merk, warna, jarak tempuh harga bekas yaitu murah dan mahal.

Harga mahal dan harga murah mobil bekas didapat dari wawancara dengan narasumber Untuk variabel kondisi sedang dan baik digunakan rumus median antar lain:

- Kondisi sedang $70 \%$

- Kondisi baik $90 \%$

Untuk warna variabelnya

- Warna favorite $81 \%$

- Tidak favorite $19 \%$

Untuk merk variabelnya

- Merk favorite 93\%

- Tidak favorite $7 \%$

Untuk jarak tempuh rutin dan jarang pakai digunakan rumus:

$$
\begin{aligned}
\text { Jarang Pakai } & =\frac{4.900}{365 \text { hari }} \\
\text { RutinPakai } & =\frac{16.415}{365 \text { hari }}
\end{aligned}
$$




\subsection{Skenario Uji Coba}

\subsubsection{Menentukan Himpunan Fuzzy dan Fungsi Keanggotaan}

Untuk Tribut kondisi dibagi menjadi 2 kategori yaitu kondisi sedang $70 \%$ dan kondisi baik 90\%. Berikut pemaparan terkait fuzzyfikasi untuk atribut kondisi. Fungsi keanggotaan:

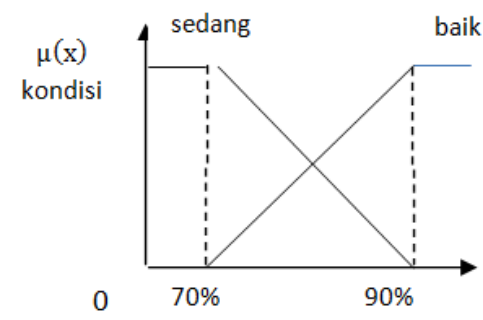

Gambar 2: Himpunan fuzzy dan Fungsi Keanggotaan Kondisi

$$
\begin{array}{r}
\mu(x) \text { kondisi sedang }=\left\{\begin{array}{cc}
1 & ; x \leq 70 \\
\frac{90-x}{90-70} & ; 70<x<90 \\
0 & x \geq 90
\end{array}\right. \\
\mu(x) \text { kondisi baik }=\left\{\begin{array}{cc}
0 & ; x \leq 70 \\
\frac{x-70}{90-70} & ; 70<x<90 \\
1 & x \geq 90
\end{array}\right.
\end{array}
$$

Pemaparan terkait fuzzyfikasi untuk atribut warna.

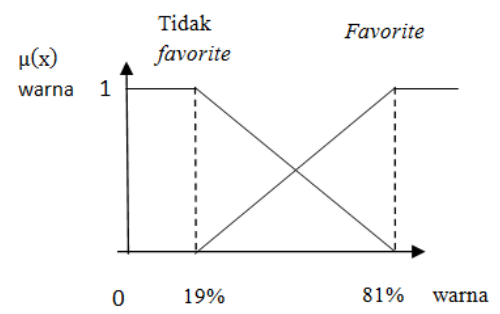

Gambar 3: Himpunan fuzzy dan Fungsi Keanggotaan Warna

$$
\begin{aligned}
\mu(x) \text { tidak favorite } & =\left\{\begin{array}{cc}
1 & ; x \leq 19 \\
\frac{81-x}{81-19} & ; 19<x<81 \\
0 & x \geq 81
\end{array}\right. \\
\mu(x) \text { favorite } & =\left\{\begin{array}{cc}
0 & ; x \leq 19 \\
\frac{x-19}{81-19} & ; 19<x<81 \\
1 & x \geq 81
\end{array}\right.
\end{aligned}
$$

Pemaparan terkait fuzzyfikasi untuk atribut merk.

$$
\begin{aligned}
\mu(x) \text { tidak favorite } & =\left\{\begin{array}{cc}
1 & ; x \leq 17 \\
\frac{93-x}{93-7} & ; 7<x<93 \\
0 & x \geq 93
\end{array}\right. \\
\mu(x) \text { favorite } & =\left\{\begin{array}{cc}
0 & ; x \leq 17 \\
\frac{x-7}{93-7} & ; 7<x<93 \\
1 & x \geq 93
\end{array}\right.
\end{aligned}
$$




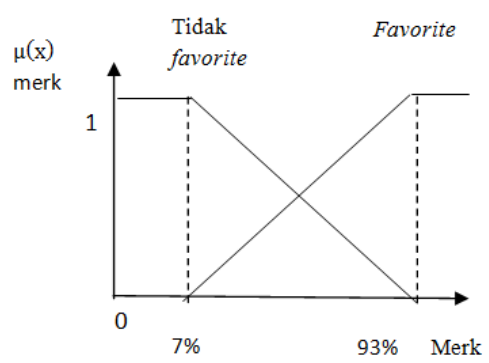

Gambar 4: Himpunan fuzzy dan Fungsi Keanggotaan Merk

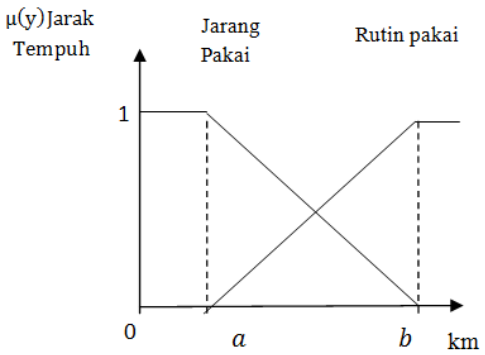

Gambar 5: Himpunan Fuzzy dan Fungsi Keanggotaan Jarak Tempuh

Pemaparan terkait fuzzyfikasi untuk atribut jarak tempuh secara umum

$$
\begin{gathered}
\mu(y) \text { jarang pakai }=\left\{\begin{array}{cc}
1 & ; y \leq a \\
\frac{b-y}{b-a} & ; a<y<b \\
0 & y \geq b
\end{array}\right. \\
\mu(y) \text { rutin pakai }=\left\{\begin{array}{cc}
0 & ; y \leq a \\
\frac{y-a}{b-a} & ; a<y<b \\
1 & y \geq b
\end{array}\right.
\end{gathered}
$$

Pemaparan terkait fuzzyfikasi untuk atribut harga bekas. Fungsi keanggotaan:

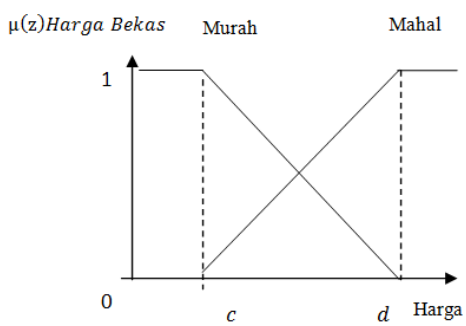

Gambar 6: Himpunan Fuzzy dan Fungsi Keanggotaan untuk Harga Bekas Mobil

$$
\begin{aligned}
& \mu(z) \text { harga bekas murah }=\left\{\begin{array}{cc}
1 & ; z \leq c \\
\frac{d-z}{d-c} & ; c<z<d \\
0 & z \geq d
\end{array}\right. \\
& \mu(z) \text { harga bekas mahal }=\left\{\begin{array}{cc}
0 & ; z \leq c \\
\frac{z-c}{d-c} & ; c<z<d \\
1 & z \geq d
\end{array}\right.
\end{aligned}
$$

\subsubsection{Menentukan Aturan-aturan yang Digunakan}

Aturan atau rule yang digunakan yaitu: 
R1 Jika kondisi baik, jarang pakai, warna favorite dan merk favorite maka harga bekas mahal.

R2 Jika kondisi baik, jarang pakai, warna favorite dan merk tidak favorite maka harga bekas mahal.

R3 Jika kondisi baik, jarang pakai, warna tidak favorite dan merk favorite maka harga bekas mahal.

R4 Jika kondisi baik, jarang pakai, warna tidak favorite dan merk tidak favorite maka harga bekas mahal.

R5 Jika kondisi baik, rutin pakai, warna favorite dan merk favorite maka harga bekas mahal.

R6 Jika kondisi baik, rutin pakai, warna favorite dan merk tidak favorite maka harga bekas mahal.

R7 Jika kondisi baik, rutin pakai, warna tidak favorite dan merk favorite maka harga bekas mahal.

R8 Jika kondisi baik, rutin pakai, warna tidak favorite dan merk tidak favorite maka harga bekas murah.

R9 Jika kondisi sedang, jarang pakai, warna favorite dan merk favorite maka harga bekas mahal.

R10 Jika kondisi sedang, jarang pakai, warna favorite dan merk tidak favorite maka harga bekas mahal.

R11 Jika kondisi sedang, jarang pakai, warna tidak favorite dan merk favorite maka harga bekas mahal.

R12 Jika kondisi sedang, jarang pakai, warna tidak favorite dan merk tidak favorite maka harga bekas mahal.

R13 Jika kondisi sedang, rutin pakai, warna favorite dan merk favorite maka harga bekas mahal.

R14 Jika kondisi sedang, rutin pakai, warna favorite dan merk tidak favorite maka harga bekas murah.

R15 Jika kondisi sedang, rutin pakai, warna tidak favorite dan merk favorite maka harga bekas murah.

R16 Jika kondisi sedang, rutin pakai, warna tidak favorite dan merk tidak favorite maka harga bekas murah.

\subsubsection{Skenario Uji Coba Perhitungan Data 1}

Mobil Honda Jazz tahun 2012 warna putih yang ingin diperkirakan harga bekasnya dengan kisaran yang telah ditentukan sebelumnya yaitu harga bekas murah sebesar Rp 160.000.000,00 dan harga bekas mahal sebesar Rp 180.000.000,00. Mobil tersebut dibeli pada tanggal 12 September 2012 dan perhitungan berlangsung pada tanggal 12 Maret 2016. Kondisi mobil tersebut $78 \%$ dan jarak yang telah ditempuh mobil tersebut adalah $38.801 \mathrm{~km}$.

$$
\begin{aligned}
\text { Kondisi } & =78 \% \\
\mu(x) \text { kondisi sedang } & =\frac{90-78}{90-70}=0,6 \\
\mu(x) \text { kondisi baik } & =\frac{78-70}{90-70}=0,4
\end{aligned}
$$


Sehingga kondisi mobil tersebut dapat dapat direpresentasikan dengan grafik kondisi sebagai berikut. Untuk mencari nilai warna digunakan penentuan ranking,berikut urutan ranking warna:

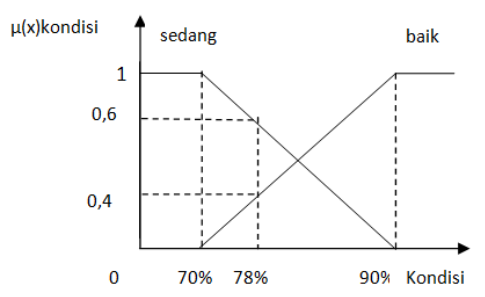

Gambar 7: Grafik Himpunan Fuzzy dan Derajat Keanggotaan Kondisi Mobil

$$
\begin{aligned}
\text { Warna putih } & =\frac{22}{43} \times 100=51 \% \\
\mu(x) \text { warna tidak favorite } & =\frac{81-51}{81-19}=0,5 \\
\mu(x) \text { warna favorite } & =\frac{51-19}{81-19}=0,5
\end{aligned}
$$

Untuk mencari nilai merk digunakan penentuan ranking,berikut urutan ranking merk:

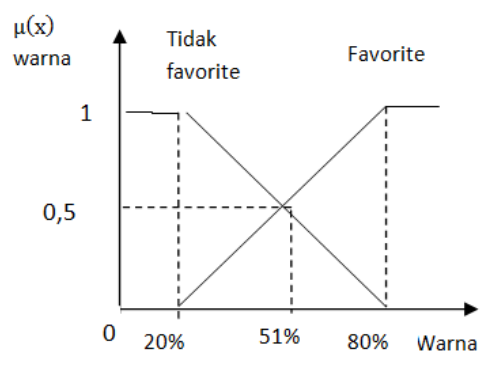

Gambar 8: Grafik uji coba Himpunan Fuzzy dan Derajat Keanggotaan Warna Mobil

$$
\begin{aligned}
\text { Merk Honda } & =\frac{22}{43} \times 100=51 \% \\
\mu(x) \text { merk tidak favorite } & =\frac{93-51}{93-7}=0,4 \\
\mu(x) \text { merk favorite } & =\frac{51-7}{93-7}=0,5
\end{aligned}
$$

Sehingga merk mobil tersebut dapat dapat direpresentasikan dengan grafik merk sebagai berikut. Untuk atribut jarak tempuh diberikan fungsi keanggotaan sebagai berikut:

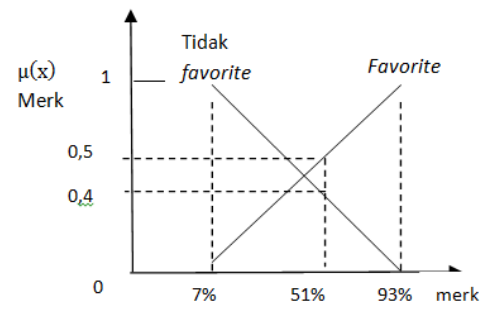

Gambar 9: Grafik uji coba Himpunan Fuzzy dan Derajat Keanggotaan Merk Mobil 


$$
\begin{aligned}
& \text { Jarang Pakai }=\frac{4.900}{365} \times 1264 \text { hari }=16.727 \mathrm{~km} \\
& \text { Rutin Pakai }=\frac{16.415}{365} \times 1264 \text { hari }=56.035 \mathrm{~km} \\
& \mu(y) \text { jarang pakai }=\frac{56.035,09-38.801}{56.035,9-16.727} \\
& =\frac{17.234,9}{39.308,9}=0,4 \\
& \mu(y) \text { rutin pakai }=\frac{30.801-16.727}{56.035,9-16.727} \\
& =\frac{22.074}{39.308,9}=0,6
\end{aligned}
$$

Untuk atribut harga bekas, dibagi menjadi 2 kategori yaitu harga bekas murah dan harga bekas

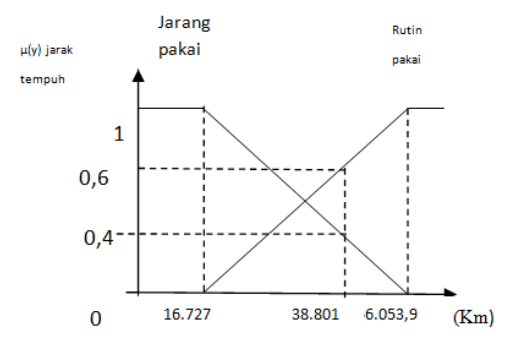

Gambar 10: Grafik uji coba Himpunan Fuzzy dan Derajat Keanggotaan jarak tempuh

mahal. Setiap mobil memiliki harga bekas murah dan harga bekas mahal yang berbeda-beda sehingga pada saat melakukan fuzzyfikasi,maka setiap mobil memiliki caranya yang berbeda-beda. Berikut pemaparan terkait fuzzyfikasi untuk atribut harga bekas.

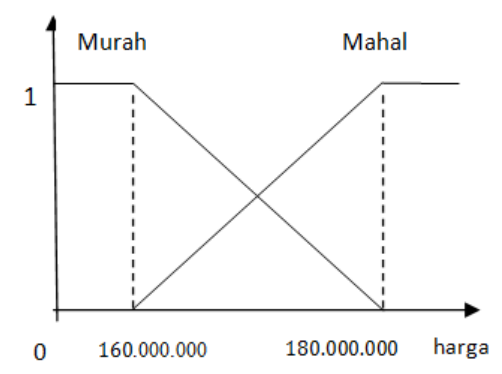

Gambar 11: Grafik uji coba Himpunan Fuzzy dan Derajat Keanggotaan Harga Bekas Mobil

$$
\begin{array}{r}
\mu(z) \text { harga bekas murah }=\left\{\begin{array}{cc}
1 & ; z \leq 160.000 .000 \\
\frac{180.000 .000-z}{180.000 .000-160.000 .000} & ; 160.000 .000<z<180.000 .000 \\
0 & z \geq 180.000 .000
\end{array}\right. \\
\mu(z) \text { harga bekas mahal }=\left\{\begin{array}{cc}
0 & ; z \leq 160.000 .000 \\
\frac{z-160.000 .000}{180.000 .000-160.000 .000} & ; 160.000 .000<z<180.000 .000(11) \\
1 & z \geq 160.000 .000
\end{array}\right.
\end{array}
$$




\subsubsection{Inferensi dan Defuzzyfikasi Menggunakan Metode Fuzzy Tsukamoto}

R1 $\alpha$ - Predikat $_{1} \mu(v)$ kondisi baik $\mu(w)$ jarang pakai $\cap \mu(x)$ warna favorite $\mu(y)$ merk favorite

$$
\begin{aligned}
& =\min (0,4 ; 0,4 ; 0,5 ; 0,5)=0,4 \\
\frac{z_{1}-160.000 .000}{180.000 .000-160.000 .000} & =0,4 \\
z_{1} & =168.000 .000
\end{aligned}
$$

R2 $\alpha-$ Predikat $_{2} \mu(v)$ kondisi baik $\mu(w)$ jarang pakai $\cap \mu(x)$ warna favorite $\mu(y)$ merk tidak favorite

$$
\begin{aligned}
& =\min (0,4 ; 0,4 ; 0,5 ; 0,4)=0,4 \\
\frac{z_{2}-160.000 .000}{180.000 .000-160.000 .000} & =0,4 \\
z_{2} & =168.000 .000
\end{aligned}
$$

R3 $\alpha-$ Predikat $_{3} \mu(v)$ kondisi baik $\mu(w)$ jarang pakai $\cap \mu(x)$ warna tidak favorite $\mu(y)$ merk favorite

$$
\begin{aligned}
& =\min (0,4 ; 0,4 ; 0,4 ; 0,5)=0,4 \\
\frac{z_{3}-160.000 .000}{180.000 .000-160.000 .000} & =0,4 \\
z_{3} & =168.000 .000
\end{aligned}
$$

R4 $\alpha$ - Predikat $_{4} \mu(v)$ kondisi baik $\mu(w)$ jarang pakai $\cap \mu(x)$ warna tidak favorite $\mu(y)$ merk tidak favorite

$$
\begin{aligned}
& =\min (0,4 ; 0,4 ; 0,4 ; 0,4)=0,4 \\
\frac{z_{4}-160.000 .000}{180.000 .000-160.000 .000} & =0,4 \\
z_{4} & =168.000 .000
\end{aligned}
$$

R5 $\alpha-$ Predikat $_{5} \mu(v)$ kondisi baik $\mu(w)$ rutin pakai $\cap \mu(x)$ warna favorite $\mu(y)$ merk favorite

$$
\begin{aligned}
& =\min (0,4 ; 0,6 ; 0,5 ; 0,5)=0,4 \\
\frac{z_{5}-160.000 .000}{180.000 .000-160.000 .000} & =0,4 \\
z_{5} & =168.000 .000
\end{aligned}
$$

R6 $\alpha-$ Predikat $_{6} \mu(v)$ kondisi baik $\mu(w)$ rutin pakai $\cap \mu(x)$ warna favorite $\mu(y)$ merk tidak favorite

$$
\begin{aligned}
& =\min (0,4 ; 0,6 ; 0,5 ; 0,4)=0,4 \\
\frac{z_{6}-160.000 .000}{180.000 .000-160.000 .000} & =0,4 \\
z_{6} & =168.000 .000
\end{aligned}
$$

R7 $\alpha-$ Predikat $_{7} \mu(v)$ kondisi baik $\mu(w)$ rutin pakai $\cap \mu(x)$ warna tidak favorite $\mu(y)$ merk favorite

$$
\begin{aligned}
& =\min (0,4 ; 0,6 ; 0,4 ; 0,5)=0,4 \\
\frac{z_{7}-160.000 .000}{180.000 .000-160.000 .000} & =0,4 \\
z_{7} & =168.000 .000
\end{aligned}
$$


R8 $\alpha$ - Predikat $_{8} \mu(v)$ kondisi baik $\mu(w)$ rutin pakai $\cap \mu(x)$ warna tidak favorite $\mu(y)$ merk tidak favorite

$$
\begin{aligned}
& =\min (0,4 ; 0,6 ; 0,4 ; 0,4)=0,4 \\
\frac{180.000 .000-z_{8}}{180.000 .000-160.000 .000} & =0,4 \\
z_{8} & =172.000 .000
\end{aligned}
$$

R9 $\alpha$ - Predikat9 $\mu(v)$ kondisi sedang $\mu(w)$ jarang pakai $\cap \mu(x)$ warna favorite $\mu(y)$ merk favorite

$$
\begin{aligned}
& =\min (0,6 ; 0,4 ; 0,5 ; 0,5)=0,4 \\
\frac{z_{9}-160.000 .000}{180.000 .000-160.000 .000} & =0,4 \\
z_{9} & =168.000 .000
\end{aligned}
$$

R10 $\alpha$ - Predikat $_{10} \mu(v)$ kondisi sedang $\mu(w)$ jarang pakai $\cap \mu(x)$ warna favorite $\mu(y)$ merk tidak favorite

$$
\begin{aligned}
\frac{z_{10}-160.000 .000}{180.000 .000-160.000 .000} & =0,4 \\
z_{10} & =168.000 .000
\end{aligned}
$$

R11 $\alpha$ - Predikat $_{11} \mu(v)$ kondisi sedang $\mu(w)$ jarang pakai $\cap \mu(x)$ warna tidak favorite $\mu(y)$ merk favorite

$$
\begin{aligned}
& =\min (0,6 ; 0,4 ; 0,4 ; 0,5)=0,4 \\
\frac{z_{11}-160.000 .000}{180.000 .000-160.000 .000} & =0,4 \\
z_{11} & =168.000 .000
\end{aligned}
$$

R12 $\alpha-$ Predikat $_{12} \mu(v)$ kondisi sedang $\mu(w)$ jarang pakai $\cap \mu(x)$ warna tidak favorite $\mu(y)$ merk tidak favorite

$$
\begin{aligned}
& =\min (0,6 ; 0,4 ; 0,4 ; 0,4)=0,4 \\
\frac{z_{12}-160.000 .000}{180.000 .000-160.000 .000} & =0,4 \\
z_{12} & =168.000 .000
\end{aligned}
$$

R13 $\alpha-$ Predikat $_{13} \mu(v)$ kondisi sedang $\mu(w)$ rutin pakai $\cap \mu(x)$ warna favorite $\mu(y)$ merk favorite

$$
\begin{aligned}
& =\min (0,6 ; 0,6 ; 0,5 ; 0,5)=0,5 \\
\frac{z_{13}-160.000 .000}{180.000 .000-160.000 .000} & =0,5 \\
z_{13} & =170.000 .000
\end{aligned}
$$

R14 $\alpha$ - Predikat $_{14} \mu(v)$ kondisi sedang $\mu(w)$ rutin pakai $\cap \mu(x)$ warna favorite $\mu(y)$ merk tidak favorite

$$
\begin{aligned}
& =\min (0,6 ; 0,6 ; 0,5 ; 0,4)=0,4 \\
\frac{180.000 .000-z_{14}}{180.000 .000-160.000 .000} & =0,4 \\
z_{14} & =172.000 .000
\end{aligned}
$$


R15 $\alpha$ - Predikat $_{15} \mu(v)$ kondisi sedang $\mu(w)$ rutin pakai $\cap \mu(x)$ warna tidak favorite $\mu(y)$ merk favorite

$$
\begin{aligned}
& =\min (0,6 ; 0,6 ; 0,4 ; 0,5)=0,4 \\
\frac{180.000 .000-z_{15}}{180.000 .000-160.000 .000} & =0,4 \\
z_{15} & =172.000 .000
\end{aligned}
$$

R16 $\alpha$ - Predikat $_{16} \mu(v)$ kondisi sedang $\mu(w)$ rutin pakai $\cap \mu(x)$ warna tidak favorite $\mu(y)$ merk tidak favorite

$$
\begin{aligned}
& =\min (0,6 ; 0,6 ; 0,4 ; 0,4)=0,4 \\
\frac{180.000 .000-z_{16}}{180.000 .000-160.000 .000} & =0,4 \\
z_{16} & =172.000 .000
\end{aligned}
$$

Defuzzifikasi

$$
z^{*}=\frac{\sum_{i=1}^{16} \alpha-\text { predikat }_{i} z_{i}}{\sum_{i=1}^{16} \alpha-\text { predikat }_{i}}
$$

\subsubsection{Defuzzyfikasi Menggunakan Metode Fuzzy Mamdani}

Himpunan grafik fuzzy baru:

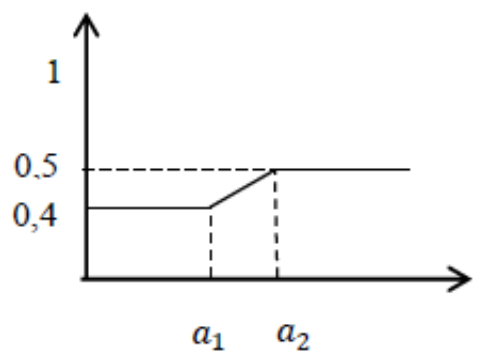

Gambar 12: Grafik Himpunan Fuzzy Baru

$$
\mu(z) \text { harga bekas }=\left\{\begin{array}{cc}
0,4 & ; z \leq 170.000 .000 \\
\frac{180.000 .000-z}{180.000 .000-160.000 .000} & ; 170.000 .000<z<172.000 .000 \\
0 & z \geq 172.000 .000
\end{array}\right.
$$

Defuzzifikasi

$$
\begin{aligned}
z^{*} & =\frac{\int_{0}^{172.000 .000} 0,4 z d z+\int_{170.000 .000}^{172.000 .000}\left(\frac{180.000 .000-z}{180.000 .000-160.000 .000}\right) j z d z+\int_{170.000 .000}^{180.000 .000} 0,5 z d z}{\int_{0}^{172.000 .000} 0,4 d z+\int_{170.000 .000}^{172.000 .000}\left(\frac{180.000 .000-z}{180.000 .000-160.000 .000}\right) j d z+\int_{170.000 .000}^{180.000 .000} 0,5 d z} \\
z^{*} & =\frac{0,\left.2\left(z^{2}\right)\right|_{0} ^{172.000 .000}+\left.\frac{-\left(\left(z^{3}\right)-270.000 .000\left(z^{2}\right)\right)}{60.000 .000}\right|_{170.000 .000} ^{172.000 .000}+0,\left.4(z)\right|_{170.000 .000} ^{180.000 .000}}{0,\left.2\left(z^{2}\right)\right|_{0} ^{172.000 .000}+\left.\frac{\left.180.000 .000(z)-\frac{z^{2}}{z}\right)}{20.000 .000}\right|_{170.000 .000} ^{172.000 .000}+0,\left.5(z)\right|_{170.000 .000} ^{180.000 .000}} \\
z^{*} & =\frac{13.393 .933 .333 .333 .333}{91.800 .000} \\
z^{*} & =151.844 .600
\end{aligned}
$$

Hasil perhitungan menunjukan bahwa metode fuzzy Tsukamoto memperkirakan harga mobil sebesar Rp.168.546.000,00, sedangkan metode fuzzy Mamdani memperkirakan harga mobil sebesar Rp.151.844.600,00. Berikut hasil perhitungan dari kedua metode tersebut dengan penyajian kreasi Paint.NET. 


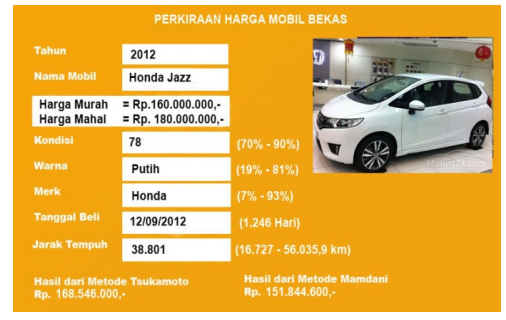

Gambar 13: Penyajian Perkiraan Harga Mobil Bekas

\section{Kesimpulan}

Hasil dari penelitian ini dapat diambil kesimpulan bahwa perkiraan Mobil bekas menggunakan metode fuzzy Tsukamoto lebih mahal dibandingkan dengan hasil perkiraan harga mobil bekas menggunakan metode fuzzy Mamdani dengan selisih rata-rata Rp.21.800.000,00 atau seki$\operatorname{tar} \pm 22 \%$.

\section{Referensi}

[1] Ulfah, "Analisis faktor-faktor terjadinya jual beli mobil bekas dikota Medan," 2011.

[2] G. Abdurahman, "Penerapan Metode Tsukamoto (Logika Fuzzy) Dalam Sistem Pendukung Keputusan untuk Menentukan Jumlah Produksi Barang berdasarkan data Persediaan dan Jumlah Permintaan," Skripsi Jurusan Matematika, Fakultas matematika dan Ilmu Pengetahuan Alam, Universitas Negeri Yogyakarta, 2011.

[3] M. Istraniady, Priko Andrian, "Analisis perbandingan Metode Fuzzy Tsukamoto dan Metode Fuzzy Mamdani pada Perbandingan Harga Sepeda Motor bekas," eprinte STMIK GI MDP Bussines School, Palembang, 2013.

[4] P. H. Kusumadewi, Sri, “Aplikasi Logika Fuzzy untuk Pendukung Keputusan,” 2004.

[5] G. Ramadhan, "Menentukan Harga Mobil Bekas Toyota Avanza Menggunakan Metode Tsukamoto," 2011.

[6] M. E. S. Sutojo, T, Kecerdasan Buatan. Yogyakarta: Andi Offset, 2011.

[7] F. Susilo, Himpunan dan Logika Kabur Serta Aplikasinya. Yogyakarta: Graha Ilmu, 2006. 